\title{
A SONG FOR MOTIVES
}

-Ginger

In praise of a blind spirit

a cantata for failure, a desire to act

only on that first idea after death.

We've been drowning for so long why not swallow this ocean, why not save this outrageous life with small gulps!

If you only knew how many hours have grown back to their first second, how many hands touching only their own legs, and the body

gasping for silence stumbles over its own disdain jumps in a sack and flings itself off

a bridge to the warmth of interstate highways.

But under the highway the same wagon road, and breaking through our control the same bloodsong. So the motive;

our wings, brooding in their dry shells

folded under the spine

let them choose to endure another blessing. 